GRASAS Y ACEITES 70 (2)

April-June 2019, e301

ISSN-L: 0017-3495

https://doi.org/10.3989/gya.0692181

\title{
Variations in oil, protein, fatty acids and vitamin $E$ contents of pumpkin seeds under deficit irrigation
}

\author{
H. Kirnak ${ }^{\mathrm{a}}$, H.A. Irik ${ }^{\mathrm{b}, \varpi}$, O. Sipahioglu ${ }^{\mathrm{c}}$ and A. Unlukara ${ }^{\mathrm{b}}$ \\ ${ }^{a}$ Department of Civil Engineering, Faculty of Engineering, Adnan Menderes University. 09010 Aydın, Turkey \\ ${ }^{b}$ Department of Biosystems Engineering, Faculty of Agriculture, Erciyes University. 38039 Kayseri, Turkey \\ ${ }^{c}$ Department of Food Engineering, Faculty of Engineering, Erciyes University. 38039 Kayseri, Turkey \\ ${ }^{\square}$ Corresponding author: haliirik42@gmail.com
}

Submitted: 11 June 2018; Accepted: 04 October 2018; Published online: 11 February 2019

SUMMARY: In the present study, pumpkin (Cucurbita Pepo L.) was grown under water stress to determine its effects on the chemical composition of the seeds (i.e., oil, protein, fatty acids and vitamin E), in Kayseri, Turkey. Irrigation treatments were designed to supply different portions of depleted moisture within the efficient root zone of the plants $(60 \mathrm{~cm})$. The treatments were arranged as supplying $100 \%\left(\mathrm{I}_{100}\right), 80 \%\left(\mathrm{I}_{80}\right), 60 \%\left(\mathrm{I}_{60}\right), 40 \%$ $\left(\mathrm{I}_{40}\right), 20 \%\left(\mathrm{I}_{20}\right)$ and $0 \%\left(\mathrm{I}_{0}\right)$ of depleted moisture through a drip irrigation system. The effects of irrigation levels on the oil content of pumpkin seeds were found to be significant $(p<0.01)$. The oil contents of irrigation treatments varied between $26 \%\left(\mathrm{I}_{0}\right.$, dry) and $64 \%\left(\mathrm{I}_{100}\right.$, full irrigation). However, the effects of deficit irrigation on protein, fatty acids and vitamin $\mathrm{E}$ contents were not found to be significant. The vitamin $\mathrm{E}$ contents varied from $41.6-55.3 \mathrm{mg} / 100 \mathrm{~g}$; while the protein contents varied from $28.5-37.7 \%$. Six different fatty acids (linolenic, linoleic, oleic, stearic, palmitic and myristic acid) were examined. The average concentration of palmitic, stearic, oleic and linoleic acids ranged from $10.7-12.6 \%, 6.4-10.4 \%, 39.6-48.9 \%$ and $32.4-35 \%$, respectively. Myristic and linolenic acids were not detected in the pumpkin seeds.

KEYWORDS: Fatty acid; Irrigation; Oil content; Pumpkin seed

RESUMEN: Variaciones en los contenidos de aceite, proteínas, ácidos grasos y vitamina $E$ de las semillas de calabaza con riego deficitario. En este trabajo se cultivaron calabazas (Cucurbita Pepo L.) en Kayseri, Turquía, con el objetivo de determinar los efectos del estrés hídrico en la composición química de las semillas (aceite, proteínas, ácidos grasos y vitamina E). Los tratamientos de irrigación se realizaron mediante el suministro de diferentes porciones de humedad dentro de la zona de la raíz eficiente de las plantas $(60 \mathrm{~cm})$. Los tratamientos se organizaron para suministrar $100 \%\left(\mathrm{I}_{100}\right), 80 \%\left(\mathrm{I}_{80}\right), 60 \%\left(\mathrm{I}_{60}\right), 40 \%\left(\mathrm{I}_{40}\right), 20 \%\left(\mathrm{I}_{20}\right)$ y $0 \%\left(\mathrm{I}_{0}\right)$ de humedad controlada a través del sistema de riego por goteo. Los efectos de los niveles de irrigación sobre el contenido de aceite de las semillas de calabaza fueron significativos ( $\mathrm{p}<0.01$ ). El contenido de aceite en función de los tratamientos de riego varió entre el $26 \%\left(I_{0}\right.$, seco) y el $64 \%$ ( $I_{100}$, riego completo). Sin embargo, los efectos del déficit de irrigación sobre los contenidos de proteínas, ácidos grasos y vitamina $\mathrm{E}$ no fueron significativos. Los contenidos de vitamina $\mathrm{E}$ variaron entre 41,6 y $55,3 \mathrm{mg} / 100 \mathrm{~g}$, mientras que los contenidos de proteína variaron entre 28,5 y $37,7 \%$. Se determinaron seis ácidos grasos (linolénico, linoleico, oleico, esteárico, palmítico y mirístico). La concentración promedio de los ácidos palmítico, esteárico, oleico y linoleico osciló entre 10,7-12,6\%, 6,4-10,4\%, 39,6-48,9\% y 32,4-35\%, respectivamente. Los ácidos mirístico y linolénico no fueron detectaron en las semillas de calabaza.

PALABRAS CLAVE: Ácido graso; Contenido de aceite; Irrigación; Semillas de calabaza

ORCID ID: Kirnak H https://orcid.org/0000-0002-6922-5457, Irik HA https://orcid.org/0000-0002-3141-0948, Sipahioglu O https://orcid.org/0000-0003-2932-6007, Unlükara A https://orcid.org/0000-0003-4931-8100

Citation/Cómo citar este artículo: Kirnak H, Irik HA, Sipahioglu O, Unlükara A. 2019. Variations in oil, protein, fatty acids and vitamin E contents of pumpkin seeds under deficit irrigation. Grasas Aceites 70 (2), e301. https://doi. org/10.3989/gya.0692181

Copyright: (C2019 CSIC. This is an open-access article distributed under the terms of the Creative Commons Attribution 4.0 International (CC BY 4.0) License. 


\section{INTRODUCTION}

Fats, fatty acids and their metabolic by-products have various significant functions in the human metabolism. They usually provide an efficient source of energy, along with resistance to external factors. They constitute the basic building blocks of cell membranes (Lee, 1994). Since omega-3 and omega-6 fatty acids are not synthesized in the human body, they should be supplied externally. They are called essential fatty acids and play significant roles in the human metabolism (Erdinc et al., 2018).

Vegetable oils are used worldwide in human nutrition, food and industrial purposes. Despite ample sources, the world's vegetable oil production mostly comes from soybean, sunflower, rapeseed and date palms. Although pumpkin seed oil has sufficient quality attributes for human nutrition and industrial purposes, it has not been used much worldwide (Stevenson et al., 2007). The oil content of pumpkin seeds generally varies from 10.9-54.0\% (Stevenson et al., 2007; Murkovic et al., 1996; Seymen et al., 2016). Pumpkin seed oil is generally used as salad dressing in Australia, Slovenia and Hungary. Although pumpkin seeds are largely used either fresh or roasted as appetizers (Murkovic et al., 1996; Ardabili et al., 2011), they have been used for medicinal purposes since ancient times.

Pumpkin seed oil is quite rich in unsaturated fatty acids and that makes it a valuable source of oil for human nutrition. Pumpkin seed oil has high oleic and linoleic unsaturated fatty acid contents and low palmitic and stearic saturated acid contents. Pumpkin seeds are also rich in vitamin $\mathrm{E}$ and protein (Ermiş, 2010). With these valuable quality attributes, pumpkin seeds prevent prostate enlargement, arthrolith, reduce cholesterol levels and regulate blood pressure (Stevenson et al., 2007). Pumpkin seeds also prevent hypertension, stimulate hyperglycemic activity and thus prevent diabetes (Stevenson et al., 2007; Fu et al., 2006; Imaeda et al., 1999). Pumpkin seeds are used as an important source of vitamin E (tochopherol) in Japanese diets.

Many physiological, molecular and biochemical reactions of plants are influenced by water stress. Seed fat and fatty acid compositions are largely influenced by the cultivar, soil and climate conditions and cultural practices (Nawirska-Olszanska et al., 2013). Parallel findings were reported in previous studies carried out with different plant species (Kaplan et al., 2017 for maize; Ali and Ullah, 2012 for sunflower; Kirnak et al., 2010, for soybean).

In Turkey, the cultivar Cucurbita pepo is commonly used and Cucurbita moschata is less frequently used for pumpkin seed production. Annually, 42181 tons of pumpkin seeds are produced from 62844.1 ha of land area in Turkey. The Kayseri province, with 15053 tons of production annually, from
31310.1 ha of land area, constitutes about $35.7 \%$ of the country's production (TUIK 2016).

Although a few studies have been conducted regarding water stress on pumpkin growth, seed yield and some seed quality properties such as 1000seed weight and oil content, no studies have been found about the effects of water stress on the other properties of pumpkin seeds. Therefore, this study was conducted to determine the effects of different irrigation regimes on oil content, fatty acids, protein and vitamin E content of pumpkin seeds produced in the central Anatolia region of Turkey.

\section{MATERIALS AND METHODS}

Experiments were conducted in the experimental fields of the Agricultural Research and Implementation Center of Erciyes University for two years, in 2015 and 2016. The research site with an altitude of $1094 \mathrm{~m}$ is located between $34^{\circ} 56^{\prime}$ and $36^{\circ} 59^{\prime}$ east longitude and between $37^{\circ} 45^{\prime}$ and $38^{\circ} 18^{\prime}$ north latitude. Long-term and 2015-2016 climate data are respectively provided in Tables 1 and 2. As can be inferred from Table 2, the precipitation throughout the experiments was $142 \mathrm{~mm}$ in 2015 and $179.4 \mathrm{~mm}$ in 2016.

Soil samples were taken from the $0-120 \mathrm{~cm}$ soil profile of 3 different locations within the research site. Water samples were taken from an irrigation water supply well and analyses were performed in accordance with Ayy1ldiz (1990). Irrigation water has a $\mathrm{pH}$ of 7.60 and EC of $242 \mu \mathrm{S}$; thus it was classified as C1S1 (Ayyldız, 1990). The results from the soil analysis are provided in Table 3 . The stable rate of infiltration was measured as $23.3 \mathrm{~mm} / \mathrm{h}$.

Experiments were conducted in a randomized block design with 3 replications. Sowing was performed with $100-\mathrm{cm}$-row spacing and $60-\mathrm{cm}$ on-row plant spacing. Since there aren't any registered varieties, the commonly-used, so-called "framed" seeds were used. Each plot had 8 rows. Two side rows and a plant row from the top and bottom sections of the plots were omitted so as to consider side-effects. About $2 \mathrm{~m}$ spacing was provided between the plots and $2.4 \mathrm{~m}$ between the blocks to prevent interactions. Based on soil analysis results, DAP fertilizer $(12 \mathrm{~kg} / \mathrm{da} \mathrm{N}, 12 \mathrm{~kg} / \mathrm{da} \mathrm{P}$ and $10 \mathrm{~kg} / \mathrm{da} \mathrm{K})$ was supplied through fertigation. Since the soil had sufficient $\mathrm{K}$ levels, $\mathrm{K}$ fertilization was not performed.

A drip irrigation system was used for irrigation. They system was designed in accordance with Keller and Bliesner (1990). Dripper spacing was $0.33 \mathrm{~m}$, dripper discharge rate was $4 \mathrm{lt} / \mathrm{h}$, lateral diameter was $20 \mathrm{~mm}$, manifold pipe diameter was $40 \mathrm{~mm}$ and main pipe line diameter was $63 \mathrm{~mm}$. Water flow meters were placed at the entrance of each block and applied water quantities were measured. The wetted area percentage was calculated as $66 \%$ (Keller and Bliesner, 1990). 
Variations in oil, protein, fatty acids and vitamin E contents of pumpkin seeds under deficit irrigation $\bullet 3$

TABLE 1. Long-term climate data for the Kayseri province (1950-2016)

\begin{tabular}{|c|c|c|c|c|c|c|c|c|c|c|c|c|}
\hline Climate Data & Jan & Feb & Mar & Apr & May & Jun & Jul & Aus & Sep & Oct & Nov & Dec \\
\hline $\mathrm{T}_{\text {avr }}\left({ }^{\circ} \mathrm{C}\right)$ & -1.7 & 0.1 & 4.7 & 10.6 & 15.0 & 19.0 & 22.2 & 22.0 & 17.3 & 11.8 & 5.5 & 0.6 \\
\hline $\mathrm{T}_{\max }\left({ }^{\circ} \mathrm{C}\right)$ & 4.1 & 6.1 & 11.4 & 17.7 & 22.5 & 26.8 & 30.6 & 30.7 & 26.5 & 20.4 & 13.0 & 6.4 \\
\hline $\mathrm{T}_{\min }\left({ }^{\circ} \mathrm{C}\right)$ & -6.9 & -5.2 & -1.4 & 3.1 & 6.8 & 9.7 & 11.9 & 11.4 & 7.3 & 3.5 & -0.9 & -4.5 \\
\hline $\mathrm{U}_{2}\left(\mathrm{~m} \cdot \mathrm{s}^{-1}\right)$ & 1.1 & 1.3 & 1.6 & 1.7 & 1.4 & 1.3 & 1.3 & 1.2 & 1.1 & 1.0 & 1.0 & 1.1 \\
\hline Precipitation (mm) & 35.2 & 36.5 & 41.8 & 52.1 & 51.8 & 39.5 & 10.5 & 8.8 & 15.0 & 28.0 & 32.4 & 37.4 \\
\hline $\mathrm{RH}_{\mathrm{avr}}(\%)$ & 76.6 & 74.0 & 68.3 & 62.3 & 61.2 & 55.8 & 49.5 & 49.2 & 54.1 & 63.6 & 71.7 & 77.1 \\
\hline $\mathrm{RH}_{\max }(\%)$ & 96.4 & 96.6 & 96.7 & 96.3 & 95.3 & 93.0 & 87.0 & 87.1 & 94.3 & 97.0 & 97.1 & 97.4 \\
\hline $\mathrm{RH}_{\min }(\%)$ & 38.8 & 34.4 & 22.5 & 18.6 & 19.0 & 19.4 & 17.2 & 16.9 & 17.4 & 20.3 & 28.2 & 36.8 \\
\hline Sunshine Duration (hour) & 3.0 & 4.0 & 4.8 & 6.2 & 8.3 & 10.4 & 11.9 & 11.4 & 9.1 & 6.7 & 4.8 & 3.0 \\
\hline Solar Radiation ( $\mathrm{MJ} \mathrm{m}^{-2}$.day) & 7.0 & 9.8 & 13.1 & 16.1 & 19.0 & 21.8 & 22.7 & 20.6 & 17.0 & 11.6 & 8.0 & 6.1 \\
\hline ETo (mm/ay) & 24 & 31 & 62 & 92 & 119 & 137 & 158 & 147 & 107 & 70 & 40 & 26 \\
\hline
\end{tabular}

$\mathrm{U}_{2}$ : Wind speed at $2 \mathrm{~m}$ height, RH: Relative Humidity, ETo: Reference Evapotranspiration.

TABLE 2. Climate data for experimental years (2015-2016)

\begin{tabular}{|c|c|c|c|c|c|}
\hline Climate Data (2015) & May & June & July & August & \\
\hline $\mathrm{T}_{\text {avr }}\left({ }^{\circ} \mathrm{C}\right)$ & 15.89 & 18.15 & 22.15 & 26.69 & \\
\hline $\mathrm{T}_{\max }\left({ }^{\circ} \mathrm{C}\right)$ & 22.55 & 24.33 & 30.06 & 32.67 & \\
\hline $\mathrm{T}_{\min }\left({ }^{\circ} \mathrm{C}\right)$ & 9.34 & 11.98 & 14.24 & 20.71 & \\
\hline Wind Speed $(\mathrm{m} / \mathrm{s})$ & 1.75 & 1.46 & 1.69 & 1.87 & \\
\hline Precipitation (mm) & 25.6 & 114.8 & 0.4 & 1.2 & \\
\hline $\mathrm{RH}_{\max }(\%)$ & 77.62 & 85.72 & 70.56 & 60.26 & \\
\hline $\mathrm{RH}_{\min }(\%)$ & 31.79 & 39.71 & 23.52 & 22.82 & \\
\hline Climate Data (2016) & April & May & June & July & August \\
\hline $\mathrm{T}_{\mathrm{avr}}\left({ }^{\circ} \mathrm{C}\right)$ & 14.02 & 14.83 & 20.41 & 23.33 & 25.38 \\
\hline $\mathrm{T}_{\max }\left({ }^{\circ} \mathrm{C}\right)$ & 20.4 & 26.7 & 34.6 & 37 & 34.8 \\
\hline $\mathrm{T}_{\min }\left({ }^{\circ} \mathrm{C}\right)$ & 4.5 & 4.4 & 7.5 & 10.8 & 14.5 \\
\hline Wind Speed $(\mathrm{m} / \mathrm{s})$ & 1.57 & 1.88 & 1.75 & 1.81 & 1.81 \\
\hline Precipitation (mm) & 0 & 151.8 & 25.6 & 2 & 0 \\
\hline $\mathrm{RH}_{\max }(\%)$ & 65.2 & 80 & 78.2 & 66.1 & 62.4 \\
\hline $\mathrm{RH}_{\min }(\%)$ & 25.5 & 34.4 & 30.8 & 21.1 & 19.99 \\
\hline
\end{tabular}

TABLE 3. Soil characteristics of the research site

\begin{tabular}{|c|c|c|c|c|}
\hline \multirow[b]{2}{*}{ Soil characteristics } & \multicolumn{4}{|c|}{ Soil depth } \\
\hline & $0-30 \mathrm{~cm}$ & $30-60 \mathrm{~cm}$ & $60-90 \mathrm{~cm}$ & $90-120 \mathrm{~cm}$ \\
\hline Texture & Loamy & Loamy & Clay-Loam & Loamy \\
\hline $\mathrm{EC}, \mathrm{dS} / \mathrm{m}$ & 0.22 & 0.173 & 0.258 & 0.191 \\
\hline $\mathrm{pH}$ & 8.13 & 8.17 & 8.14 & 8.23 \\
\hline Field Capacity, $\mathrm{Pw}_{\mathrm{FC}}(\%)$ & 23 & 26 & 26 & 25 \\
\hline Permanent Wilting Point, $\mathrm{PW}_{\mathrm{PWP}}(\%)$ & 10.73 & 11.38 & 9.3 & 9.37 \\
\hline Bulk Density, $\mathrm{g} / \mathrm{cm}^{3}$ & 1.27 & 1.24 & 1.22 & 1.28 \\
\hline Organic Matter, $\%$ & 1.25 & 1.05 & 0.69 & 0.73 \\
\hline Lime, $\%$ & 2.54 & 5.83 & 3.15 & 6.2 \\
\hline $\mathrm{N}, \mathrm{kg} / \mathrm{ha}$ & 21.5 & 10.5 & 4.00 & 4.00 \\
\hline $\mathrm{P}_{2} \mathrm{O}_{5}, \mathrm{~kg} / \mathrm{ha}$ & 20.5 & 11.5 & 6.00 & 2.00 \\
\hline $\mathrm{K}_{2} \mathrm{SO}_{4}, \mathrm{~kg} / \mathrm{ha}$ & 271.6 & 376.4 & 310.1 & 310.1 \\
\hline
\end{tabular}


Soil moisture levels within the $120 \mathrm{~cm}$ soil profile were monitored on every other day with a neuron meter (CPN 503DR Hydroprobe) and irrigation was initiated when $35-40 \%$ of available water within the root zone was depleted. Plant efficient root depth was taken as $60 \mathrm{~cm}$ (Allen et al., 1998). Irrigation intervals varied during the growing season because of irrigation scheduling based on soil moisture depletion. In total, irrigation was carried out 12 times in 2015 and 10 times in 2016.

Different irrigation levels were experimented in this study. Experimental irrigation levels were created through supplying different portions of depleted moisture within the efficient root zone of the plants. The treatments were arranged as supplying $100 \%\left(\mathrm{I}_{100}\right), 80 \%\left(\mathrm{I}_{80}\right), 60 \%\left(\mathrm{I}_{60}\right), 40 \%\left(\mathrm{I}_{40}\right), 20 \%$ $\left(\mathrm{I}_{20}\right)$ and $0 \%\left(\mathrm{I}_{0}\right)$ of depleted moisture.

Sowing was performed on 5 May, 2015 and 29 April, 2016 and harvesting was done on 24 August, 2015 and 10 August, 2016. Irrigation programs were initiated on 19 June, 2015 in the first year and on 13 June, 2016 in the second year. Chemicals were not applied since there were not any pests or diseases.

\subsection{Chemical analyses performed on pumpkin seeds}

\subsubsection{Seed vitamin $\mathbf{E}$ contents}

The vitamin E concentration of pumpkin seeds was determined with the aid of a liquid chromatography system (AOAC, 2000). The sample preparation process was composed of two basic stages. The first stage was the saponification stage of a certain quantity of sample with potassium hydroxide in a water-ethanol ambient. In the second stage, the nonsaponified fraction was extracted with hexane. The resultant extract was evaporated in a nitrogen ambient and analyzed in the liquid chromatography system. The seeds were ground and the oil was extracted. The resultant extract was then subjected to vitamin $\mathrm{E}$ analysis. About $0.1 \mathrm{~g}$ sample was weighed on a precise balance $( \pm 0.0001 \mathrm{~g})$ and placed into screwedcap test tubes. The oil samples were supplemented with $0.2 \mathrm{~g}$ ascorbic acid as antioxidant. The samples were then supplemented with $5.5 \mathrm{~mL}$ saponification solution ( $45 \%$ water, $55 \%$ ethanol, $11 \% \mathrm{KOH}(\mathrm{w} / \mathrm{v})$ ). The residual air over the samples was removed with nitrogen gas. The test tubes were screwed-tight, and placed in a heated ultrasonic water bath for 30 minutes at $80{ }^{\circ} \mathrm{C}$ for saponification. The samples were cooled down instantly and passed to the liquid-liquid extraction phase. The samples were initially supplemented with $1.5 \mathrm{~mL}$ distilled water and then with $3 \mathrm{~mL}$-hexane and vortexed for 3 minutes to obtain a homogeneous mixture. The Tubes were centrifuged at $2000 \mathrm{rpm}$ for 10 minutes to accelerate phase separation. The upper hexane phase of the centrifuged samples was taken into $30 \mathrm{~mL}$ vials. The same extraction process was repeated and the resultant hexane gas was added to the previous portion. The hexane phase in $30 \mathrm{~mL}$ vials was then evaporated through nitrogen flow. The residue left over the bottom of the vial was dissolved in $0.5 \mathrm{ml}$ methanol and sample preparation was finalized. HPLC analyses were performed in an Agilent 1100 series LC system. Separation was performed in an analytic column filled with $250 \times 4.6 \mathrm{~mm}$ size $5 \mu \mathrm{m}$ diameter particles. Chromatograms were recorded with the aid of measurements made at $325 \mathrm{~nm}$ wave length with an Agilent 1100 Diode Series Detector. Vitamin E concentrations were determined from the peaks of the chromatograms.

\subsubsection{Seed oil analysis}

The oil analysis of pumpkin seeds was performed with the aid of the Soxhlet method (AACC, 2000). Seeds were ground and dried before the analyses and oil was extracted from the seeds with petroleum ether. The solvent evaporated and the remaining portion was dried to constant weight at $100{ }^{\circ} \mathrm{C}$.

\subsubsection{Seed protein analysis}

The automatic nitrogen determination device (Leco, ABD) operating in accordance with Dumas principles was used for protein analyses. For this purpose, about $0.2 \mathrm{mg}$ sample were placed in the pre-heated Leco FP 528 nitrogen analyzer at $850{ }^{\circ} \mathrm{C}$ and nitrogen contents were directly read from the device.

\subsubsection{Fatty acid composition of seeds}

Ground and dried seed samples were subjected to fatty acid composition analyses in a Gas Chromatographer (Tulukcu et al., 2012). Initially, previously extracted and frozen samples $\left(-24^{\circ} \mathrm{C}\right)$ were thawed and $100 \mathrm{mg}$ sample were placed in $15 \mathrm{ml}$ centrifuge tubes. For the methylation process, the samples were supplemented initially with $100 \mu \mathrm{L}$ $2 \mathrm{~N} \mathrm{KOH}$ and then with $3 \mathrm{~mL}$ hexane. The samples were vortexed for 15 seconds to obtain a homogeneous mixture and centrifuged at $5000 \mathrm{rpm}$ for 5 minutes. Following the centrifuge, $1.5 \mathrm{~mL}$ upper phase were transferred into vials and made ready for fatty acid composition analyses in the gas chromatographer (Agilent 6890, Ariz., ABD) equipped with an Atom Ionizing Detector equipped with an ID HP-88 column (100 $\mathrm{m}$ long and $0.25 \mathrm{~mm}$ in diameter). The injection temperature was $250{ }^{\circ} \mathrm{C}$; oven temperature was $103{ }^{\circ} \mathrm{C}$. Temperature was increased 1 minute later from $103{ }^{\circ} \mathrm{C}$ to $170{ }^{\circ} \mathrm{C}$ with a $6.5^{\circ} \mathrm{C}$ increase per minute, and then increased from $170{ }^{\circ} \mathrm{C}$ to $215^{\circ} \mathrm{C}$ with a $2.75^{\circ} \mathrm{C}$ increase per minute. Finally, the temperature was set at $230^{\circ} \mathrm{C}$ for 5 minutes. Helium was used as the carrier gas at a flow rate of $2 \mathrm{~mL} / \mathrm{min}$. The split ratio was $1 / 50$. 
The total analysis duration was about 40 minutes and at the end of this period, the device software was used to determine the detention times of the fatty acids. Comparisons were made with standard retention times to identify each fatty acid. Results were expressed as $\%$ of total fatty acid composition.

\subsection{Statistical analysis}

Data were subjected to variance analysis using SAS (SAS Inst., 1999) statistical software. The LSD multiple range test was employed to compare the treatment means as a complement of the ANOVA procedure.

\section{RESULTS}

Irrigation water quantities applied to pumpkin seed plants in $\mathrm{I}_{0}, \mathrm{I}_{20}, \mathrm{I}_{40}, \mathrm{I}_{60}, \mathrm{I}_{80}$ and $\mathrm{I}_{100}$ treatments were measured as $24,70.8,117.9,164.6,211.4$ and 258.4 $\mathrm{mm}$, respectively, in 2015 and as 13, 104.4, 195.8, 287.3, 378.8 and $470.2 \mathrm{~mm}$, respectively, in 2016 .

The vitamin E contents, fatty acids, oil and protein contents of different irrigation treatments are provided in Table 4.
While different irrigation treatments did not have significant effects on the vitamin E contents of the pumpkin seeds in 2015, the effects of irrigation treatments on vitamin $\mathrm{E}$ contents were found to be significant in 2016 (Table 5). Vitamin E contents varied from $41.6-55.3 \mathrm{mg} / 100 \mathrm{~g}$ in 2015 and from $45.0-55.3$ $\mathrm{mg} / 100 \mathrm{~g}$ in 2016. The lowest vitamin E content was obtained from $\mathrm{I}_{40}$ treatments in 2015 and 2016 and the greatest vitamin $\mathrm{E}$ content was obtained from $\mathrm{I}_{20}$ treatment in 2015 and from $\mathrm{I}_{60}$ treatment in 2016.

Linoleic, linolenic, oleic, stearic, palmitic and meristic acids were investigated in pumpkin seeds and linolenic and meristic acids were not encountered in the seeds. Although linolenic and meristic acids are among the main components of pumpkin seed, these acids are included in trace levels and some researchers could not determine linolenic or meristic acid (Potočnik et al., 2018; Meru et al., 2018; Lazos, 1986; Rezig et al., 2012). Irrigation treatments did not result in significant changes in the fatty acid compositions of the pumpkin seeds in either year (Table 5). Linoleic acid contents varied from $33.0-34.35$ in 2015 and from $32.4-35.0 \%$ in 2016. Oleic acid was the dominant fatty acid in both years. Oleic acid contents varied from $45.3-48.9 \%$

TABLE 4. Effects of different irrigation treatments on fatty acids, oil, protein and vitamin E contents of pumpkin seeds

\begin{tabular}{cclcccccc}
\hline Year & Treatments & $\begin{array}{c}\text { Vitamin E } \\
(\mathbf{m g} / \mathbf{1 0 0} \mathbf{g})\end{array}$ & $\begin{array}{c}\text { Linoleic acid } \\
\mathbf{( \% )}\end{array}$ & $\begin{array}{c}\text { Oleic acid } \\
\mathbf{( \% )}\end{array}$ & $\begin{array}{c}\text { Palmitic acid } \\
\mathbf{( \% )}\end{array}$ & $\begin{array}{c}\text { Stearic acid } \\
(\%)\end{array}$ & $\begin{array}{c}\text { Oil content } \\
(\%)\end{array}$ & $\begin{array}{c}\text { Protein content } \\
(\%)\end{array}$ \\
\hline 2015 & $\mathrm{I}_{0}$ & $51.9 \pm 3.83$ & $33.8 \pm 2.15$ & $45.3 \pm 2.58$ & $10.9 \pm 0.25$ & $7.6 \pm 1.19$ & $26 \pm 1.98 \mathrm{c}$ & $32.2 \pm 0.19$ \\
& $\mathrm{I}_{20}$ & $55.3 \pm 9.01$ & $34.3 \pm 0.68$ & $47.3 \pm 0.70$ & $10.7 \pm 0.51$ & $7.7 \pm 0.44$ & $35 \pm 5.94 \mathrm{~b}$ & $30.6 \pm 2.30$ \\
& $\mathrm{I}_{40}$ & $41.6 \pm 1.65$ & $34.1 \pm 1.25$ & $45.5 \pm 2.69$ & $12.4 \pm 1.23$ & $8.5 \pm 0.58$ & $45 \pm 2.77 \mathrm{a}$ & $29.9 \pm 3.98$ \\
& $\mathrm{I}_{60}$ & $46.0 \pm 4.40$ & $33.0 \pm 0.75$ & $48.9 \pm 0.31$ & $11.3 \pm 0.39$ & $6.9 \pm 0.14$ & $49 \pm 2.01 \mathrm{a}$ & $29.8 \pm 2.43$ \\
& $\mathrm{I}_{80}$ & $46.1 \pm 4.17$ & $34.2 \pm 0.50$ & $48.4 \pm 1.61$ & $11.1 \pm 0.14$ & $6.4 \pm 1.06$ & $45 \pm 5.80 \mathrm{a}$ & $28.5 \pm 2.09$ \\
& $\mathrm{I}_{100}$ & $46.8 \pm 5.66$ & $33.9 \pm 1.96$ & $48.2 \pm 1.84$ & $11.3 \pm 0.19$ & $6.7 \pm 0.20$ & $51 \pm 0.31 \mathrm{a}$ & $29.4 \pm 1.18$ \\
& $\mathrm{I}_{0}$ & $47.4 \pm 8.64 \mathrm{bc}$ & $32.4 \pm 3.98$ & $39.6 \pm 4.16$ & $11.5 \pm 0.94$ & $10.4 \pm 0.80$ & $58 \pm 3.22 \mathrm{~b}$ & $37.7 \pm 1.53 \mathrm{a}$ \\
& $\mathrm{I}_{20}$ & $50.4 \pm 6.87 \mathrm{abc}$ & $34.4 \pm 3.16$ & $43.9 \pm 3.07$ & $10.8 \pm 0.70$ & $10.3 \pm 0.29$ & $60 \pm 2.54 \mathrm{ab}$ & $34.7 \pm 1.51 \mathrm{ab}$ \\
& $\mathrm{I}_{40}$ & $45.0 \pm 7.27 \mathrm{c}$ & $34.0 \pm 1.31$ & $43.4 \pm 0.62$ & $11.7 \pm 1.00$ & $10.4 \pm 0.28$ & $59 \pm 4.73 \mathrm{~b}$ & $34.8 \pm 0.59 \mathrm{ab}$ \\
& $\mathrm{I}_{60}$ & $53.9 \pm 7.64 \mathrm{ab}$ & $33.4 \pm 4.03$ & $44.5 \pm 3.81$ & $12.4 \pm 1.04$ & $9.2 \pm 0.99$ & $61 \pm 4.60 \mathrm{ab}$ & $33.2 \pm 3.19 \mathrm{bc}$ \\
& $\mathrm{I}_{80}$ & $48.2 \pm 11.49 \mathrm{bc}$ & $35.0 \pm 2.95$ & $43.1 \pm 3.19$ & $12.6 \pm 1.22$ & $9.1 \pm 0.80$ & $64 \pm 3.94 \mathrm{a}$ & $29.61 .61 \pm \mathrm{c}$ \\
& $\mathrm{I}_{100}$ & $55.3 \pm 2.26 \mathrm{a}$ & $34.5 \pm 0.80$ & $43.8 \pm 0.77$ & $11.8 \pm 0.73$ & $9.6 \pm 0.86$ & $64 \pm 2.89 \mathrm{a}$ & $32.3 \pm 4.41 \mathrm{bc}$ \\
\hline
\end{tabular}

In the table each value represents the mean \pm standard deviation of the tree replicates of the analyses

TABLE 5. Level of significance (P) from the variance analyses of chemical components of pumpkin seeds

\begin{tabular}{|c|c|c|c|c|c|c|c|c|}
\hline Source of Variations & D.F. & $\begin{array}{l}\text { Vitamin E } \\
(\mathrm{mg} / 100 \mathrm{~g})\end{array}$ & $\begin{array}{c}\text { Linoleic acid } \\
(\%)\end{array}$ & $\begin{array}{c}\text { Oleic acid } \\
(\%)\end{array}$ & $\begin{array}{c}\text { Palmitic acid } \\
(\%)\end{array}$ & $\begin{array}{c}\text { Stearic acid } \\
(\%)\end{array}$ & $\begin{array}{l}\text { Oil } \\
(\%)\end{array}$ & Protein (\%) \\
\hline \multicolumn{9}{|l|}{2015} \\
\hline $\begin{array}{l}\text { Irrigation Level } \\
2016\end{array}$ & 5 & $0.122 \mathrm{~ns}$ & $0.828 \mathrm{~ns}$ & $0.187 \mathrm{~ns}$ & $0.096 \mathrm{~ns}$ & $0.062 \mathrm{~ns}$ & $0.0001 * *$ & $0.242 \mathrm{~ns}$ \\
\hline Irrigation Level & 5 & $0.024 *$ & $0.932 \mathrm{~ns}$ & $0.952 \mathrm{~ns}$ & $0.190 \mathrm{~ns}$ & $0.070 \mathrm{~ns}$ & $0.020^{*}$ & $0.0185^{*}$ \\
\hline
\end{tabular}

ns: Non significant *: Significant at $5 \%$ level and **: significant at $1 \%$ level. 

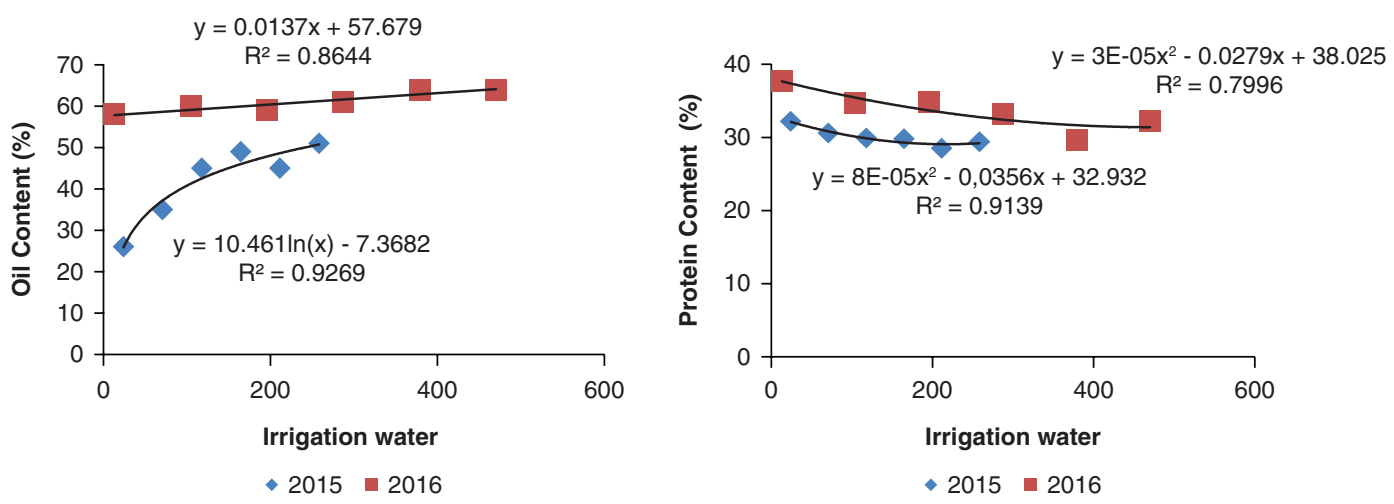

In the figureeach value represents the mean \pm standard deviation of the tree replicates of the analyses

FIGURE 1. Relationships between irrigation water quantities and oil and protein contents of pumpkin seeds

in 2015 and from $39.6-44.5 \%$ in 2016. Palmitic acid contents varied from $10.7-12.4 \%$ in 2015 and from $10.8-12.6 \%$ in 216 . The stearic acid contents of the pumpkin seeds varied from $6.4-8.5 \%$ in 2015 and from $9.1-10.4 \%$ in 2016 . Fatty acids exhibited similar variations in both years.

Irrigation treatments had significant effects on the oil contents of the pumpkin seeds in both years (Table 5). Oil contents varied from $26-51 \%$ in 2015 and from 58-64\% in 2016. In 2015, the lowest oil content was obtained from the $\mathrm{I}_{0}$ treatment and the greatest oil content was obtained from the $\mathrm{I}_{100}$ treatment. There were three statistical groups in 2015 and the $\mathrm{I}_{100}, \mathrm{I}_{80}, \mathrm{I}_{60}$ and $\mathrm{I}_{40}$ treatments were placed in the same statistical group. In 2016, the lowest oil content was obtained from $\mathrm{I}_{0}$ and the greatest oil content was obtained from the $\mathrm{I}_{100}$ treatment. There were two statistical groups in 2016 and the $\mathrm{I}_{20}, \mathrm{I}_{60}$, $\mathrm{I}_{80}$ and $\mathrm{I}_{100}$ treatments were placed in the same statistical group. The oil contents in the seeds increased with increasing irrigation water quantities.

While irrigation treatments did not have significant effects on the protein contents of the pumpkin seeds in 2015, the effects of irrigation treatment on protein contents were found to be significant in 2016 (Table 5). In both years, the greatest protein content was obtained from the $\mathrm{I}_{0}$ treatment and the lowest oil content was obtained from the $\mathrm{I}_{80}$ treatment. Protein contents decreased with increasing irrigation treatments.

The relationships between the applied irrigation water quantities and the oil and protein contents in the pumpkin seeds are presented in Figure 1. Irrigation water quantities significantly correlated with oil and protein contents. There was a significant logarithmic relationship between irrigation water quantities and oil contents in $2015\left(\mathrm{R}^{2}=0.93\right)$ and a linear relationship was observed in $2016\left(R^{2}=0.86\right)$. On the other hand, there were polynomial relationships between irrigation water quantities and protein contents $\left(R^{2}=0.91, R^{2}=0.80\right.$, respectively) in both years.

\section{DISCUSSION}

Pumpkin seed production has increasing popularity compared to cereals because of profitability, easy storage and marketing. Rich oil, fatty acids, protein and vitamin $\mathrm{E}$ contents increase the significance of pumpkin seed cultivation even more.

Pumpkin seeds are quite rich in vitamin E. Rezig et al., (2012) reported the vitamin E contents of pumpkin seeds (Cucurbita maxima) as $41.9 \mathrm{mg} / 100 \mathrm{~g}$. Stevenson et al., (2007) worked with pumpkin seeds of 12 different cultivars and reported vitamin E contents between 45.4 and $70.9 \mathrm{mg} / 100 \mathrm{~g}$. In another study carried out in Iran, the average vitamin E content in pumpkin seeds (Cucurbita pepo Subsp. pepo Var) was reported as $88.8 \mathrm{mg} / 100 \mathrm{~g}$ (Ardabili et al., 2007). The present findings comply with those earlier ones. Vitamin $\mathrm{E}$ is a natural antioxidant. The vitamin E contents in pumpkin seed oil largely depend on the fatty acid contents and compositions of the seeds. Vitamin E contents are also greatly influenced by post-harvest conditions (Nakic et al., 2006). Environmental conditions affect the fatty acids, amino acids, minerals and vitamins of different pumpkin genotypes (Erdinç et al., 2018). Because the vitamin E content of pumpkin seed depends on water stress and other factors, we may not find regular effects of water stress on vitamin E.

Pumpkin seeds were mostly composed of linoleic, oleic, palmitic and stearic acids. Pumpkin seeds generally had high unsaturated fatty acid (Linoleic+Oleic) contents. Fatty acid contents varied from 79.1-82.65 in 2015 and from $72-78.3 \%$ in 2016. Stevenson et al., (2007) reported the unsaturated fatty acid contents of pumpkin seeds as between 73.1-80.5\%. Meru et al., (2018) reported the unsaturated fatty acid contents as between $78.6-86.1 \%$. Oleic acid was the dominant fatty acid in the present study and it was followed by linoleic acid. The present findings were in good agreement with the findings of Nakic et al., (2006). The lowest acids were identified as stearic $(6.4-10.4 \%)$ and palmitic acids $(10.7-12.6 \%)$. The present findings 
comply with the results of earlier studies (Lazos 1986; Sekerci et al., 2017; Nawirska-Olszanska et al., 2013; Seymen et al., 2016).

Pumpkin seed oils are mostly unrefined. Therefore, they are not used as cooking oil, but mostly used as salad dressing because of the color, strong aroma and fatty acid composition. Linoleic acid usually reduces the heat balance of the oil, thus it not suitable to be used as cooking oil (Nederal et al., 2012; Potacnik et al., 2018).

The Present oil contents (26-64\%) comply with the findings of earlier studies carried out with cucurbita species. Meru et al., (2018) reported the oil contents of pumpkin seeds as between 29.33 and $48.41 \%$. Lazos (1986) reported the average oil content of pumpkin seeds as $45.4 \%$ and Ardabili et al., (2011) as 41.6\%. In another study, the oil contents of pumpkin seeds were reported as between 10.9 and $30.9 \%$ (Stevenson et al., 2007). Differences in oil contents of the seeds largely depend on cultivars, agricultural practices and water management regimes.

The present protein contents also comply with the findings of previous studies. Glew et al., (2006) reported the average protein content of pumpkin seeds as 51.4\%, Lazos (1986) as 32\% and Ardabili et al., (2011) as 25.4\%. Al-Khalifa (1996) reported the protein contents as $26.5 \%$ for Cucurbita pepo and 24\% for Cucurbita moschata. The Present protein contents varied from $28.5-37.7 \%$. These values are lower than the values reported by Glew et al., (2006), but well comply with the findings of other studies. Differences in protein contents are mostly attributed to differences in cultivars, growing conditions and climate parameters.

\section{CONCLUSIONS}

The pumpkin seeds of this experiment have high vitamin E content, which makes them desirable for human health. Vitamin E content was not changed with irrigation water amounts. Although water stress decreased the oil's components, fatty acid content was not significantly changed. Oil content was improved by increasing irrigation amounts and the highest oil content was acquired by applying full irrigation. Oleic, linoleic, palmitic and stearic acids were the main components of the pumpkin seeds. Irrigation also improved pumpkin seed protein content. We concluded that pumpkin seed properties are beneficial for human health and their production could be hastened by proper irrigation management strategies.

\section{ACKNOWLEDGEMENTS}

The authors would like to thank the Turkish Scientific and Technical Research Council (TUBITAK) for financial support to the project of TOVAG-1140225.

\section{REFERENCES}

AACC. Approved Methods. 2000.10th ed, American Association of Cereal Chemists, St. Paul, MN.

Ali A, Ullah S. 2012. Effect of nitrogen on achene protein, oil, fatty acid profile, and yield of sunflower hybrids. Chilean Ar. 72, 564-567.

Al-Khalifa AS. 1996. Physicochemical characteristics, fatty acid composition, and lipoxygenase activity of crude pumpkin and melon seed oils. J. Agric. Food Chem. 44, 964-966.

Allen RG, Pereira LS, Raes D, Smith M. 1998. Crop evapotranspiration: guidelines for computing crop water requirements. Irrigation and Drainage, Paper No.56. FAO, Rome, Italy.

AOAC, 2000. Official Methods of Analysis of AOAC International. 17th ed. Association of Official Analytical Chemists, Washington, DC.

Ardabili AG, Farhoosh R, Haddad Khodaparast MH. 2011. Chemical composition and physicochemical properties of pumpkin seeds (Cucurbita pepo Subsp. Pepo Var. Styriaka) grown in Iran. J. Agr. Sci. Tech. 13, 1053-1063

Ayyıldız A. 1990. Irrigation water quality and salinity problems. Ankara University, Faculty of Agriculture Textbook, Ankara.

Erdinç C, Seymen M, Türkmen Ö, Fidan S, Paksoy M. 2018. Mineral composition of inbred confectionary pumpkin candidates from Turkey originated populations. I Igdtr. Univ. J. Inst. Sci. Tech. 8, 11-17. https://doi.org/10.21597/ jist. 405759

Ermiş S. 2010. The effect of ecology on seed production and snack quality of pumpkin (Cucurbita pepo L.) in Turkey. Ankara University Graduate School of Natural and Applied Sciences Department of Horticulture, Ankara, $153 \mathrm{~s}$.

Fu CL, Shi H, Li QH. 2006. A review on pharmacological activities and utilization technologies of pumpkin. Plant Foods Hum. Nut. 61, 73-80.

Glew RH, Glew RS, Chuang LT, Huang YS, Millson M, Constants D, Vanderjagt DJ. 2006. Amino acid, mineral and fatty acid content of pumpkin seeds (Cucurbitaspp) and Cyperusesculentus nuts in the Republic of Niger. Plant Food Hum. Nutr. 61, 51-56. https://doi.org/10.1007/ s11130-006-0010-Z

Imaeda N, Tokudome Y, Ikeda M, Kitagawa I, Fujiwara N, Tokudome S. 1999. Foods contributing to absolute intake and variance in intake of selected vitamins, minerals and dietary fiber in middle-aged Japanese. J. Nutr. Sci. Vitaminol. 45, 519-532.

Kaplan M, Kale H, Karaman K, Unlükara A. 2017. Influence of different irrigation and nitrogen levels on crude oil and fatty acid composition of maize (Zea mays L.). Grasas Aceites 68, 1-6. https://doi.org/10.3989/gya.0222171

Keller J, Bliesner R. 1990. Sprikle and trickle irrigation. Chapman and Hall, New York, NY 10003. USA.

Kirnak H, Dogan E, Turkoglu H. 2010. Effect of drip irrigation intensity on soybean seed yield and quality in the semi-arid Harran plain, Turkey. SJAR 8, 1208-1217.

Lazos ES. 1986. Nutritional, fatty acid and oil characteristics of pumpkin and melon seeds. J. Food Sci. 51, 1382-1383.

Lee RMKV.1994. Fish oil, essential fatty acids and hypertension. Can. J. Physiol. Pharmacol. 72, 945-953.

Meru G, Fu Y, Levya D, Sarnoski P, Yagiz Y. 2018. Phenotypic relationships among oil, protein, fatty acid composition and seed size traits in Cucurbita pepo. Sci. Hortic. 233, 47-53. https://doi.org/10.1016/j.scienta.2018.01.030

Murkovic M, Hillebrand A, Winkler J, Leitner E, Pfannhauser W. 1996. Variability of fatty acid content in pumpkin seeds (Cucurbita pepo L.). Z. Lebensm. Unters. Forsch. 203, 216-219.

Nakic SN, Rade D, Skevin D, Strucelj D, Mokrovcak Z, Bartolic M. 2006. Chemical characteristics of oils from naked and husk seeds of Cucurbita pepo L. Eur. J. Lipid Sci. Technol. 108, 936-943. https://doi.org/10.1002/ejlt.200600161

Nawirska-Olszanska A, Kita A, Biesiada A, Sokol-Letowska A, Kucharska AZ. 2013. Characteristics of antioxidant activity and composition of pumpkin sedd oils in 12 cultivars. Food Chem. 139, 155-161. https://doi.org/10.1016/j. foodchem.2013.02.009 
Nederal S, Skevin D, Kraljic K, Obranovic M, Papesa S, Bataljaku A. 2012. Chemical composition and oxidantive stability of roasted and cold pressed pumpkin seed oils. J. Am. Oil Chem. Soc. 89, 1763-1770.

Potacnik T, Cizej MR, Kosir IJ. 2018. Influence of seed roasting on pumpkin seed oil tocopherols, phenolics and antiradical activity. J. Food Compos. Anal. 69, 7-12. https://doi. org/10.1016/j.jfca.2018.01.020

Rezig L, Chouaibi M, Msaada K, Hamdi S. 2012. Chemical composition and profile characterization of pumpkin (Cucurbita maxima) seed oil. Ind. Crops Prod. 37, 82-87. https://doi.org/10.1016/j.indcrop.2011.12.004

SAS Institute Inc. 1999. SAS/GRAPH Software: Reference, Version 8, Cary, NC: SAS Institute Inc.

Sekerci AD, Karaman K, Yetisir H, Sagdic O. 2017. Change in morphological properties and fatty acid composition of ornamental pumpkin seeds (Cucurbita pepo var. ovifera) and their classification by chemometric analysis. J. Food Meas. Charact. 11, 1306-1314. https://doi.org/10.1007/ s11694-017-9508-3

Seymen M, Uslu N, Türkmen O, Juhaimi FA, Özcan MM. 2016. Chemical composition and mineral contents of some hullless pumpkin seed and oils. J. Am. Oil. Chem. Soc. 93, 1095-1099.

Stevenson DG, Eller FJ, Wang L, Jane JL, Wang T. 2007. Oil and tocopherol content and composition of pumpkin seed oil in 12 cultivars. J. Agric. Food Chem. 55, 4005-4013.

TUIK 2016 (Turkish Statistical Institute), http://www.turkstat. gov.tr/Start.do

Tulukcu E, Yalcin H, Ozturk I, Sagdic O. 2012. Changes in the fatty acid compositions and bioactivities of clary sage seeds depending on harvest year. Industrial Crops Products 36, 69-73. 